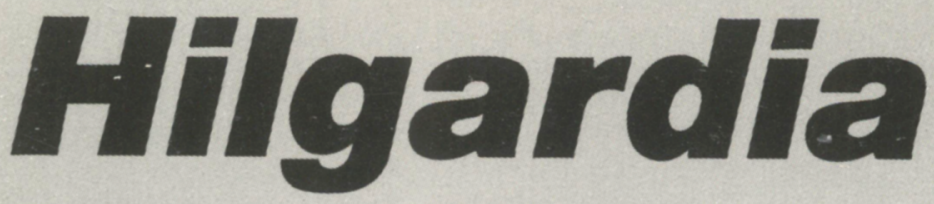

A. JOURNAL OF AGRICULTURAL SCIENCE PUBLISHED BY THE CALIFORNIA AGRICULTURAL EXPERIMENT STATION

Volume 54 - Number 3 - March 1986

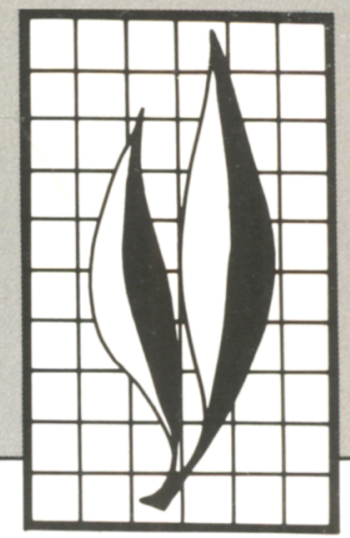

\title{
An Ecological Comparison of Spiders from Urban and Natural Habitats
} in California

Jack B. Fraser and Gordon W. Frankie 


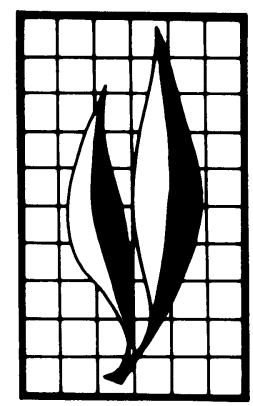

\begin{abstract}
A comparative study of spider communities in urban, native, and semi-native habitats was conducted in 1980 in northern California. Selected biotic and abiotic factors thought to be responsible for observed differences in spider-community composition among habitats were investigated.

Three backyards in the city of Berkeley comprised the urban study site. Plants found at this site included: Sequoia sempervirens, Juniperus sabina 'Tamariscifolia,' Hedera belix, Camellia japonica, and various annual and perennial flowers. Spider-community composition at the urban habitat consisted primarily of web-building spiders above ground level (aerial). Ground-surface spiders were fewer in number and species due to manipulation of the environment by homeowners.

A relatively undisturbed coastal chaparral habitat, $7.7 \mathrm{~km}$ east of Berkeley (in Contra Costa County), was chosen to represent the native site. A limited number of plant species and structural diversity was characteristic of this habitat. Baccharis pilularis, Lupinus albifrons, Lupinus bicolor, and various grasses (Avena fatua, Bromus mollis, etc.) dominated the plant community at this study site, Briones Reservior. Total numbers and numbers of species of aerial spiders were low at this habitat. However, ground-surface spiders were more numerous, probably due to an abundance of prey.

A semi-native habitat (Tilden Park) located between the urban and native habitats shared plant species with both these habitats. Plant species included both ornamental plants (Juniperus sabina, Pyracantba sp., and Prunus sp.) and native plants (Quercus agrifolia and Baccharis pilularis). The climate was most similar to the native habitat, although
\end{abstract}

\title{
THE AUTHORS:
}

Jack B. Fraser is an entomologist, Western Regional Research Center, Agricultural Research Service, U.S. Department of Agriculture, Albany, CA 94710.

Gordon W. Frankie is professor of entolomogy, Department of Entomology, University of California, Berkeley, CA 94720. 


\section{An Ecological Comparison of Spiders from Urban and Natural Habitats in California ${ }^{1}$}

\section{INTRODUCTION}

MANY TYPES OF HABITATS in relation to the spider-community structure have been studied. A few examples include sand dunes (Lowrie 1948), soybeans (Culin and Rust 1980), cotton (Whitcomb, Exline, and Hunter 1963), forests (Turnbull 1960), and apple orchards (Specht and Dondale 1960). However, spiders in urban habitats have received little study. The urban habitat has been established by humans and as such has several unique attributes. For example, urban climates are generally warmer than nearby rural areas due to paved surfaces and buildings (Landsberg 1981). Vegetation is typically a mixture of ornamentals, weeds, and native plant species (Schmid 1975; Frankie and Koehler 1980). The unique character of urban flora has been described for several cities (Gill and Bonnett 1973; Hawksworth 1974; Schmid 1975). Perhaps the most prominent attributes are the continued presence and activities of human beings.

Previous studies on urban spiders have been limited in scope, often only resulting in lists of spider species and short descriptions of associated plant species. Potential insect prey that occurred in the studied habitat are occasionally included. Residential yards in Florida were included in a study of ground-surface spiders (Muma 1973), but this was mostly a species listing with few comments on community structure. Kaston (1983) discussed the association of spiders with human-made structures. Davis (1979) correlated the number of spider species from pitfall traps in London with the amount of open space, and Duffey (1974) discussed habitat selection of some spiders in human-made structures. Vincent and Frankie (1985) compared spider samples from urban and native live oak in Texas. However, an examination of the potential influences of both abiotic and biotic parameters on urban spider community structure remains to be done.

A comparative study of residential yards, a relatively undisturbed chaparral plant community, and site-sharing characteristics of both urban and native habitats was conducted in the San Francisco Bay Area of California from June to November 1980 to explore relationships of specific habitat features to resident spider species. The following general question formed the basis of the study: What are the abiotic and biotic factors that influence spider species composition in a community, and how do they compare among these three habitats? More specifically, (1) Does plant diversity and/or architecture influence what spider species are present? (2) Does climate influence the presence or absence of a particular spider species? (3) Is there a correlation between available insect prey and spider species at these habitats? (4) What effects do human disturbances on a habitat have on spider communities?

Spider communities, in this study, refer to a collection of species occupying a specific habitat at a specific time. No determinations of the boundaries of the reproductive population of each species are offered. It is recognized that the spider community indicated for each habitat is only a representative sample; however, we contend these samples are indicative of these habitats.

${ }^{1}$ Accepted for publication December 10, 1985. 


\section{Study Site Descriptions}

\section{Urban habitat: Berkeley backyards}

Backyards of three homes in Berkeley, California were selected for this study. Their owners agreed not to use pesticides or to tamper with sampling equipment during the study period.

Each yard (G1, G2, and G3) differed in shape, size, plant composition, and plant distribution (Fraser 1983). Plants in two of the yards (G1 and G2) surrounded a central lawn; no lawn was present at G3 (fig. 1). Study areas of each yard were: $\mathrm{G} 1-56.5 \mathrm{~m}^{2}$, $\mathrm{G} 2-73.0 \mathrm{~m}^{2}$, and $\mathrm{G} 3-68.0 \mathrm{~m}^{2}$.

The urban yards experienced only a narrow range in mean weekly temperatures $\left(7^{\circ} \mathrm{C}\right)$ that can best be described as cool to warm during daylight hours (table 1). The highest temperature recorded was $27.8^{\circ} \mathrm{C}$; a nighttime low was $10^{\circ} \mathrm{C}$. The mean weekly relative humidity range was great, with a recorded high of 96.0 percent and low of 35.0 percent.

Plant-life forms in urban yards varied from annual flowers to trees. Plant species found in more than one yard included: Rose (Rosa sp.), lemon (Citrus sp.), California redwood (Sequoia sempervirens), and English ivy (Hedera belix). Although some plant species were found in common among the residences, many were unique to a given location (Fraser 1983). Numbers of ornamental plant species varied in yards from 8 to 27 ; and there was little dominance by just one or two plant species.

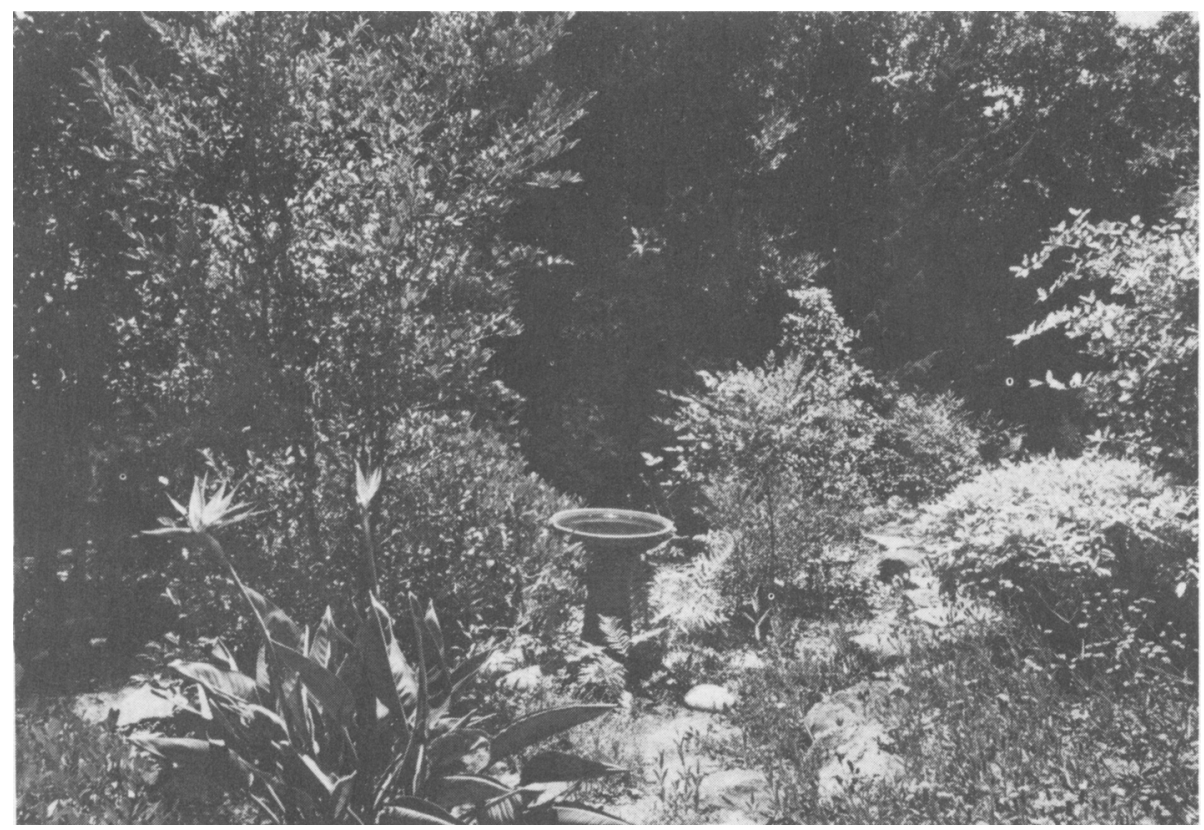

Fig. 1. Vegetation in yard G3 
A continuum of owner disturbance was observed at the three urban yards. At G1, owners did little except infrequently water a lemon tree and cut the grass every 3 to 4 weeks. More maintenance time was spent on G2, including weekly waterings, pruning, weeding, planting different annuals, and weekly lawn cutting. At G3 owner activity was similar to that at G2, but more extensive. The Briones and Tilden sites remained virtually unaltered by human activities during the study.

\section{Native habitat: Briones Reservior}

Briones Reservoir is located in East Bay Municipal Utilities District (EBMUD) watershed land, $7.7 \mathrm{~km}$ east of Berkeley in the eastern foothills of the Berkeley hills. This property has remained unchanged for more than 10 years and may be considered a slightly disturbed chaparral plant community as defined by Munz (1968) (fig. 2). The specific study site consisted of one large area of $167 \mathrm{~m}^{2}$, which was slightly smaller than the combined area of the urban yards.

The climate at Briones differed considerably from that recorded at the urban yards (table 1). The mean weekly temperature range was greater at Briones with a high daytime temperature of $36.4^{\circ} \mathrm{C}$ and a nighttime low of $7.2^{\circ} \mathrm{C}$. In general, many of the days could be described as warm or hot. Briones was a noticeably drier site with a recorded high humidity of 64.0 percent and a low of 26.0 percent.

The plant community at Briones consisted primarily of the native coyote brush (Baccharis pilularis) and lupine (Lupinus spp.), and various introduced annual grasses (Avena fatua, Bromus racemosus, etc.) (Fraser 1983).

\section{Tilden Park site: Semi-native habitat}

The $192 \mathrm{~m}^{2}$ study site was located in the Tilden Park nature area, an East Bay Regional Park in the Berkeley hills, $3.5 \mathrm{~km}$ east of Berkeley and $4.2 \mathrm{~km}$ west of Briones. The study site consisted of two subsites of nearly equal size (subsite $1=80 \mathrm{~m}^{2}$ and subsite $2=112 \mathrm{~m}^{2}$ ). The spatial and geographical relationships of all three habitats are presented in figure 3.

Plant community composition at Tilden was a mixture of native and ornamental plant species (Fraser 1983). The most common native species incuded: California live oak (Quercus agrifolia), poison oak (Rubus vitifolius), California bay (Umbellularia californica),

TABLE 1. MEAN WEEKLY HIGH AND LOW AND ACTUAL RANGE OF TEMPERATURES AND RELATIVE HUMIDITIES AT THE URBAN GARDENS, BRIONES, AND TILDEN, RECORDED FROM JUNE TO NOVEMBER 1980

\begin{tabular}{lcccccc}
\hline \hline Site & $\begin{array}{c}\overline{\mathbf{X}} \text { weekly } \\
\text { high and low } \\
\text { temperatures }\end{array}$ & $\begin{array}{c}\text { Highest } \\
\text { temperature }\end{array}$ & $\begin{array}{c}\text { Lowest } \\
\text { temperature }\end{array}$ & $\begin{array}{c}\overline{\mathbf{X}} \text { weekly } \\
\text { high and low } \\
\text { relative humidity }\end{array}$ & $\begin{array}{c}\text { Highest } \\
\text { relative } \\
\text { humidity }\end{array}$ & $\begin{array}{c}\text { Lowest } \\
\text { relative } \\
\text { humidity }\end{array}$ \\
\hline & $\left({ }^{\circ} \mathrm{C}\right)$ & $\left({ }^{\circ} \mathrm{C}\right)$ & $\left.{ }^{\circ} \mathrm{C}\right)$ & $(\%)$ & $(\%)$ & $(\%)$ \\
Urban & $12.9-19.7$ & 27.8 & 10.0 & $55.2-92.3$ & 96.0 & 35.0 \\
Briones & $9.6-24.6$ & 36.4 & 7.2 & $35.5-51.6$ & 64.0 & 26.0 \\
Tilden & $4.9-23.2$ & 37.0 & -4.0 & $50.0-97.0$ & 97.0 & 34.0 \\
\hline
\end{tabular}


and coyote brush (Baccharis pilularis). Some ornamental plants at this site were: plum (Prunus sp.), tam juniper (Juniperus sabina 'Tamariscifolia'), and firethorn (Pyracantba sp.). Several introduced weedy plants found at the Tilden site were: wild oat (Avena fatua), soft chess (Bromus mollis), and french broom (Cytisus monspessulanus).

The mean temperatures recorded at Tilden were most similar to Briones. However, the range between mean high and mean low was somewhat greater than at Briones $\left(18.3^{\circ} \mathrm{C}\right)$ as was the range in recorded extreme temperatures $\left(-4.0^{\circ} \mathrm{C}\right.$ to $\left.37.8^{\circ} \mathrm{C}\right)$. In contrast to Briones, the range in high and low humidities was greater with a recorded high of 97.0 percent and a low of 34.0 percent. The urban site and Tilden were similar in humidity.

Although the three habitats were within $7.7 \mathrm{~km}$ of each other, dramatic differences in climate existed. A major factor accounting for these differences was the maritime influence. Berkeley is located on the eastern shore of San Francisco Bay and its weather is affected by its proximity to the bay and to the Pacific Ocean. Tilden is situated in a valley within the Berkeley hills so maritime influence is lessened. Briones Reservoir, located in the eastern foothills of the Berkeley hills, is the least affected by maritime influences.

\section{MATERIALS AND METHODS}

Three techniques were used to sample arthropods from June to November 1980 at each study site. These were: sticky boards, pitfall traps, and visual search.

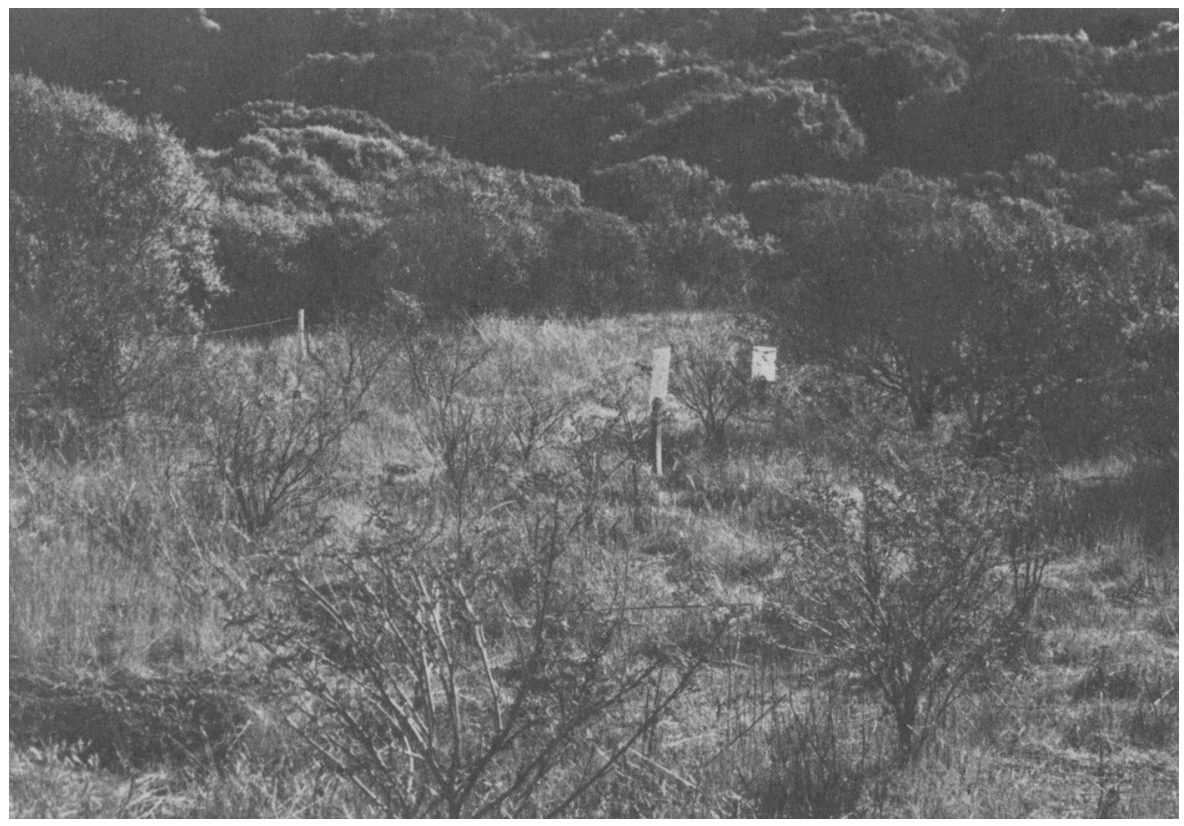

Fig. 2. Chaparral habitat at Briones Reservoir 
To sample flying insects, sticky boards were constructed of $15 \mathrm{~cm} \times 20 \mathrm{~cm}$ clear plexiglass sheets painted with a thin layer of Stickem Special. Three boards were attached perpendicularly by wooden holders to a wood pole, each at a different height: $46 \mathrm{~cm}$, $137 \mathrm{~cm}$, and $168 \mathrm{~cm}$, and the boards all faced in one direction. One sticky board pole was installed in each urban yard, at Briones, and in each of two subsites in Tilden. Boards were set up every 6 weeks for a sampling period of 4 days, beginning in July and ending in November. After each sample period, boards were removed and all insects counted and

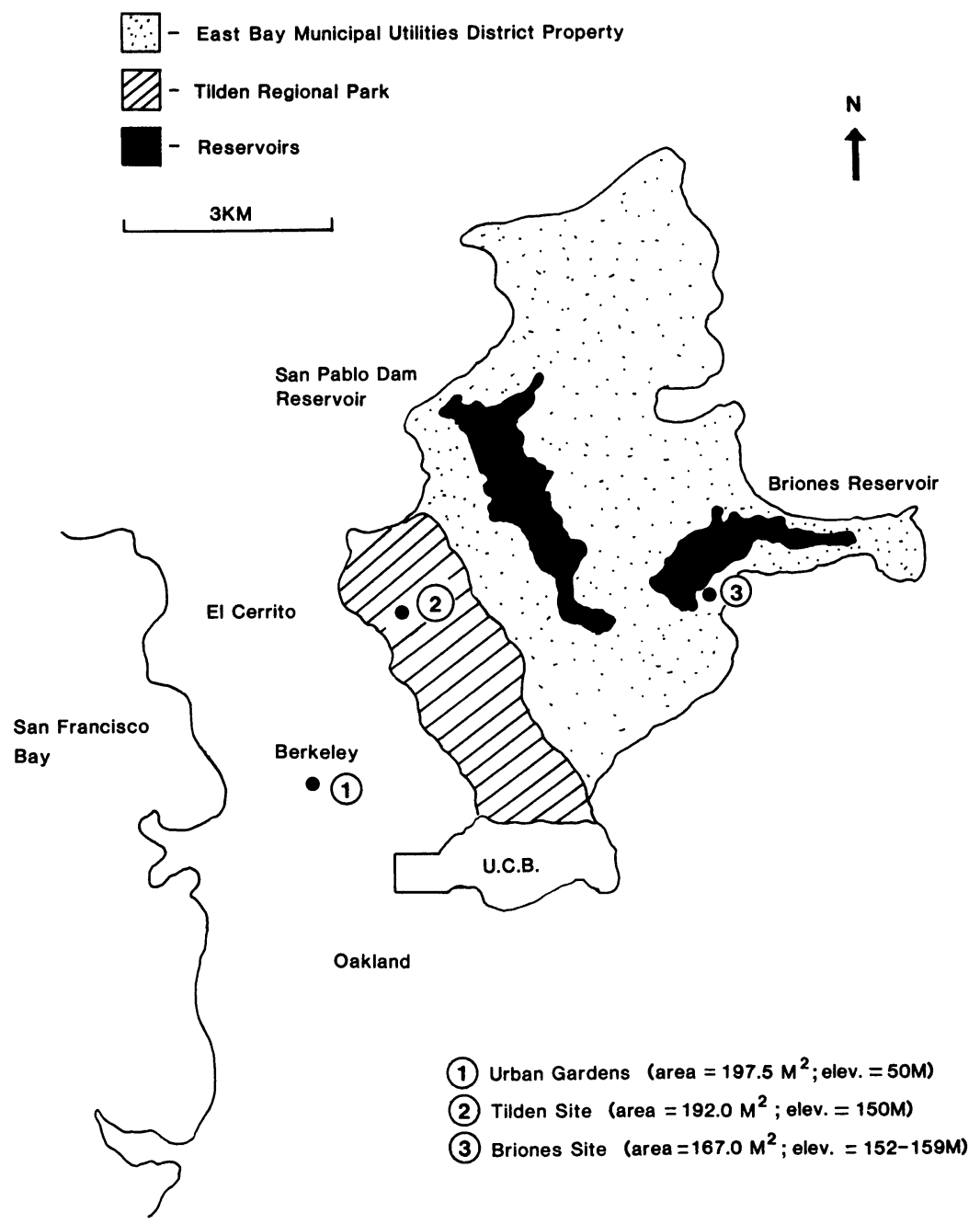

Fig. 3. Geographic and spatial relationships of the three study sites (U.C.B. = University of California, Berkeley) 
classified to order. Samples were stored in paint thinner for later identification as to family, some individuals as to genus and morpho-species. The category morpho-species was used because of time limitations, considering the enormous amount of material to be identified. Although an effort was made to separate distinct individuals, it is possible that different morpho-species did include morphs of the same species. However, since we wanted only a general estimate of the numbers and kinds of insects found in a habitat, this procedure was considered adequate.

This study modified the pitfall trap designed by Uetz and Unzicker (1976). The trap's body, a plastic one-quart freezer jar, had a removable fine-mesh nylon net at the bottom, submerged beneath the preservative (180-360 $\mathrm{ml}$ of ethylene glycol). Although there has been some controversy over the value and representativeness of pitfall trap samples (Greenslade 1964; Southwood 1978), they remain one of the few methods available for collecting samples of ground-wandering insects and spiders (Uetz and Unzicker 1976). The primary objection to pitfall trapping is that the trap may preferentially collect arthropods dependent on their activity within the habitat structure present. We have found that visual searches inadequately sample cursorial spiders; pitfall traps offered the next best method. Use of pitfall traps limited analysis to numbers of spiders and insects caught with the realization that although the sampling would not trap all cursorial spiders and insects within the different habitats, it allowed simple comparisons between them.

At each urban yard and each Tilden subsite four pitfall traps were used for a total of 12 and 8 traps, respectively. One trap was placed at each cardinal point per plot. Because of the rectangular shape of the Briones plot, cardinal-point sampling would have left large areas of the plot unsampled. Based on this consideration, traps were spaced equidistantly, three traps along each of the long sides of the plot for a total of six traps. Half the traps were alternately open or closed at each site for each 2-week sample period. In the case of the Briones plot, the two end traps on one long side and the middle trap of the opposite long side were alternated. After 2 weeks, the content of the open traps were removed and stored in 70 percent ethanol and the traps covered. Traps that had been closed were then opened for the next 2 weeks. All traps at a site were not opened at one time because of the possibility of depleting arthropod populations. For comparing pitfall trap catches among sites, the catch from one trap at Briones was randomly selected and discarded.

The third sampling method was a visual search for spiders at ground and all vegetation levels. In the case of web-building spiders, this technique has been shown to be one of the most effective methods (Lubin 1978). Every 2 weeks one-third of a site's area (divided into quadrants) was chosen, using a random numbers table. These quadrants were visually searched for spiders from ground level to $210 \mathrm{~cm}$ with the aid of a hand-held water sprayer. Vegetation sprayed with a fine mist made webs more noticeable. Sampling usually required from 1 to $1 \frac{1}{2}$ hours per site and was performed only during daylight hours. When a spider was found, the plant, spider species, and height of the spider on the plant were recorded. If the spider species was unknown, it was collected for identification.

The three sampling techniques used in this study provided values for several categories of variables. From pitfall traps and sticky boards total numbers of insects captured and the numbers of insect morpho-species per sample could be determined. Total numbers of spiders and spider species captured per sample were recorded from pitfall traps and visual samples. Pearson correlation coefficients were calculated for all pairwise comparisons of these variables using the SPSS program (Nie et al. 1975). 
Daily recordings of temperatures and relative humidity were taken from hygrothermographs that were continuously run at the following three study sites: G1, Briones, and Tilden. G1 was chosen among the three urban yards only for convenience of operation. Accuracy of hygrothermographs was periodically checked with a thermometer and sling psychrometer.

A structural profile of each plant species found within the plots was determined by taking a $13 \mathrm{~cm} \times 15 \mathrm{~cm}$ grid made from hardware cloth and counting the number of squares with vertical and horizontal plant parts as seen through the grid when placed against vegetation. Counts were taken from ground level to $210 \mathrm{~cm}$, and from these a graphic representation of the number of vertical and horizontal components of each plant was drawn (Curtis and Bignal 1978). Based on these data, the amount of vegetative cover at each height and percentage of total vegetation at each height were calculated.

The architectural arrangement of plant species at a site was measured as a ratio between vertically and horizontally oriented vegetation. This vertical/horizontal index was calculated from the plant structural profiles compiled for all plant species at a site. Index values greater than 1.0 indicated a high proportion of vertically oriented vegetation; conversely, a value less than 1.0 indicated a high proportion of horizontally oriented vegetation.

The Shannon-Weiner diversity index was used to calculate plant species diversity using the species diversity program of Orr et al. (1970). Amount of plant coverage was used in place of number of individual plants for calculating the plant species diversity index (Murdoch, Evans, and Peterson 1972).

Because only three backyards were used to represent the urban habitat, other nearby cities were surveyed to verify that the Berkeley yards were representative in numbers and kinds of plants and in species of spiders found in the San Francisco Bay Area. Six Bay Area cities were surveyed: Oakland, Berkeley, El Cerrito, San Rafael, Burlingame, and Orinda Village. In each city 20 backyards (total of $n=120$ ) were randomly selected using a random numbers table and searched visually for 15 minutes, with the aid of a hand-held water sprayer. All detected spiders were identified and recorded and unknowns were captured for later identification. The number of plant species in each yard was also recorded, and the amount of care devoted to maintaining the yard was estimated, as judged by the amount of duff, weeds, dried-out plants, unpruned plants, etc.

\section{RESULTS}

\section{Sampling Techniques}

\section{Sticky boards: Insects}

All study sites differed in total insects captured on a per-sample basis. Total numbers of insects caught on sticky boards were 1155, 1640, and 2238 at Tilden, urban yards, and Briones, respectively. Mean numbers of insects at Briones were found to be significantly higher than either the urban yards or Tilden, with no statistical difference between mean numbers of insects from the urban yards and Tilden (table 2). Mean numbers of insect morpho-species at Briones and Tilden 1 (i.e., subsite 1) were significantly greater than 
those for yards G1 and G3. Yard G2 and the nonurban sites had similar mean numbers of insect morpho-species. No consistent pattern for insect numbers was found for different heights on the sticky boards.

A greater total number of insect families and morpho-species was collected at Tilden than at Briones or the urban yards (see Appendix A and Fraser 1983). The urban yards were second in number of morpho-species collected, although one more insect family was represented from Briones. Tilden shared 30 morpho-species in 15 families with the urban yards and 32 morpho-species in 23 families with Briones. Briones and the urban yards shared 21 morpho-species in 17 families.

Sticky board samples at all sites were dominated by high numbers of Diptera, Hymenoptera, Thysanoptera, Aphidae, and Pscoptera. Collectively, these orders accounted for approximately 99 percent, 96 percent, and 86 percent of the samples in the urban yards, Briones, and Tilden, respectively. Dipterans were most prevalent at the urban yards and Tilden where their numbers constituted the highest percentage of all samples. However, one Thysanoptera morpho-species contributed more than 40 percent of insect numbers at every level at Briones. Hymenopterans were the second most abundant order in the urban environment and Tilden, although they were third in rank at Briones behind Diptera. Insect composition did not vary much among height levels at any study site.

\section{Pitfall traps: Insects}

Mean number of insects captured in pitfall traps was greatest at G2, which was significantly greater than that recorded for any other site (table 2). The higher mean at this yard was due primarily to large numbers of two carabid species. Briones had the second

TABLE 2. MEAN NUMBERS OF INSECTS AND INSECT MORPHO-SPECIES ( \pm SD) SAMPLED FROM STICKY BOARDS AND PITFALL TRAPS AT URBAN YARDS, BRIONES, AND TILDEN (MEANS FOLLOWED BY SAME LETTER HORIZONTALLY ARE NOT STATISTICALLY DIFFERENT ACCORDING TO DUNCAN'S MEAN SEPARATION $p=0.05$ )*

\begin{tabular}{|c|c|c|c|c|c|c|}
\hline \multirow{3}{*}{$\begin{array}{l}\text { Sampling } \\
\text { techniques }\end{array}$} & \multicolumn{3}{|c|}{ Urban yards } & \multicolumn{3}{|c|}{ Nonurban } \\
\hline & \multirow[t]{2}{*}{ G1 } & \multirow[t]{2}{*}{ G2 } & \multirow[t]{2}{*}{ G3 } & \multirow[t]{2}{*}{ Briones } & \multicolumn{2}{|c|}{ Tilden } \\
\hline & & & & & Subsite 1 & Subsite 2 \\
\hline \multicolumn{7}{|l|}{ Sticky boards } \\
\hline $\begin{array}{l}\overline{\mathrm{X}} \text { no. of } \\
\text { insects }\end{array}$ & $\begin{array}{c}91.4 \\
\pm 67.2 \mathrm{a}\end{array}$ & $\begin{array}{r}134.8 \\
\pm 65.2_{\mathrm{a}}\end{array}$ & $\begin{array}{r}102.1 \\
\pm 57.9 \mathrm{a}\end{array}$ & $\begin{aligned} & 447.6 \\
\pm & 292.0_{b}\end{aligned}$ & $\begin{array}{c}240.0 \\
\pm 146.6_{a}\end{array}$ & $\begin{array}{c}164.4 \\
\pm 82.4 a\end{array}$ \\
\hline $\begin{array}{l}\overline{\mathrm{X}} \text { no. of } \\
\text { morpho-species }\end{array}$ & $\begin{array}{l}13.2 \\
\pm 4.1_{\mathrm{b}}\end{array}$ & $\begin{aligned} & 19.4 \\
\pm & 5.3_{\mathrm{a}, \mathrm{b}}\end{aligned}$ & $\begin{array}{r}13.6 \\
\pm 4.7 \mathrm{~b}\end{array}$ & $\begin{array}{r}21.6 \\
\pm 4.0_{a}\end{array}$ & $\begin{array}{r}24.6 \\
\pm 8.4_{a}\end{array}$ & $\begin{aligned} & 20.6 \\
\pm & 4.4_{\mathrm{a}, \mathrm{b}}\end{aligned}$ \\
\hline \multicolumn{7}{|l|}{ Pitfall traps } \\
\hline $\begin{array}{l}\overline{\mathrm{X}} \text { no. of } \\
\text { insects }\end{array}$ & $\begin{array}{c}52.7 \\
\pm 24.5 \mathrm{~b}\end{array}$ & $\begin{array}{r}173.4 \\
\pm 93.6_{a}\end{array}$ & $\begin{array}{c}40.2 \\
\pm 25.5 b\end{array}$ & $\begin{aligned} & 59.7 \\
\pm & 44.1_{b}\end{aligned}$ & $\begin{array}{c}38.5 \\
\pm 26.3_{b}\end{array}$ & $\begin{aligned} & 52.7 \\
\pm & 35.6 \mathrm{~b}\end{aligned}$ \\
\hline $\begin{array}{l}\overline{\mathrm{X}} \text { no. of } \\
\text { morpho-species }\end{array}$ & $\begin{array}{r}11.1 \\
\pm 3.4 \mathrm{a}\end{array}$ & $\begin{aligned} & 15.8 \\
\pm & 3.8_{\mathrm{a}, \mathrm{b}}\end{aligned}$ & $\begin{aligned} & 11.6 \\
\pm & 3.7 \mathrm{a}\end{aligned}$ & $\begin{array}{r}11.5 \\
\pm 6.7 \mathrm{a}\end{array}$ & $\begin{array}{c}14.1 \\
\pm 4.4_{\mathrm{a}, \mathrm{b}}\end{array}$ & $\begin{array}{r}19.5 \\
\pm 5.5 \mathrm{~b}\end{array}$ \\
\hline
\end{tabular}

*Numbers of sticky boards at a site were: each urban yard-3, Briones-3, each Tilden subsite-3.

Numbers of pitfall traps operational during each sample period were: each urban yard-2, Briones-3, each Tilden subsite- 2 (the catch from one Briones trap was deleted when comparing sites). 
highest mean number of insects per sample; the lowest mean occurred at Tilden. Mean numbers of morpho-species were significantly different between Tilden (subsite 2) and yards $\mathrm{G} 1$ and $\mathrm{G} 2$.

Samples were dominated by morpho-species in Coleoptera, Hymenoptera, and Diptera (Appendix B). These three orders constituted nearly 80 percent of all morpho-species captured at any site. The most diverse number of families and morpho-species was collected at Tilden. Tilden shared more morpho-species with Briones ( 27 morpho-species) than with the urban yards ( 17 morpho-species). The urban yards and Briones shared 22 families and a mean of 15.6 morpho-species.

\section{Pitfall traps: Spiders}

Mean numbers of spiders and spider species captured in pitfall traps during a sample period also differed between study sites (table 3). Mean numbers of spiders and spider species at Tilden and Briones were significantly higher than in the urban yards; overall, urban yards exhibited low numbers of species. Considering only the urban yards, G1 had a significantly higher mean number of spiders and spider species than either G2 or G3 (ANOVA $F=6.0, p=0.05$ ). Between Briones and Tilden, mean numbers of spiders were similar; however, mean numbers of species were significantly higher at Tilden 1 compared with Briones.

Three families dominated spider pitfall trap catches at Briones and the urban site (table 4). Gnaphosidae, Agelenidae, and Lycosidae accounted for 80 percent of all spiders at the urban site and 79 percent at Briones. At Tilden, they comprised 66 percent of all spiders captured.

\begin{tabular}{|c|c|c|c|c|c|c|}
\hline \multirow{3}{*}{$\begin{array}{l}\text { Traps/ } \\
\text { Visual samples }\end{array}$} & \multicolumn{3}{|c|}{ Urban yards } & \multicolumn{3}{|c|}{ Nonurban } \\
\hline & \multirow[t]{2}{*}{ G1 } & \multirow[t]{2}{*}{ G2 } & \multirow[t]{2}{*}{ G3 } & \multirow[t]{2}{*}{ Briones } & \multicolumn{2}{|c|}{ Tilden } \\
\hline & & & & & Subsite 1 & Subsite 2 \\
\hline \multicolumn{7}{|l|}{ Pitfall traps } \\
\hline$\overline{\mathrm{X}}$ no. of spiders & $\begin{array}{l}7.6 \\
\pm 6.1_{b}\end{array}$ & $\begin{aligned} & 1.9 \\
\pm & 1.8_{\mathrm{b}}\end{aligned}$ & $\begin{array}{l}1.2 \\
\pm 0.6_{\mathrm{b}}\end{array}$ & $\begin{array}{c}20.6 \\
\pm 16.1_{a}\end{array}$ & $\begin{aligned} & 29.6 \\
\pm & 25.1_{a}\end{aligned}$ & $\begin{array}{c}24.1 \\
\pm 10.7 \mathrm{a}\end{array}$ \\
\hline$\overline{\mathrm{X}}$ no. of species & $\begin{array}{c}3.4 \\
\pm 1.7_{c}\end{array}$ & $\begin{array}{c}1.7 \\
\pm 1.6_{c}\end{array}$ & $\begin{array}{c}1.1 \\
\pm 0.5 c\end{array}$ & $\begin{aligned} & 6.7 \\
\pm & 4.1_{\mathrm{b}}\end{aligned}$ & $\begin{array}{l}9.9 \\
\pm \\
4.7 \mathrm{a}\end{array}$ & $\begin{aligned} & 9.3^{\circ} \\
\pm & 3.9 \mathrm{a}, \mathrm{b}\end{aligned}$ \\
\hline \multicolumn{7}{|l|}{ Visual samples } \\
\hline$\overline{\mathrm{X}}$ no. of spiders & $\begin{array}{c}44.2 \\
+24.2_{\mathrm{a}}\end{array}$ & $\begin{aligned} & 25.6 \\
\pm & 14.1_{b, c}\end{aligned}$ & $\begin{aligned} & 16.1 \\
\pm & 12.0_{c, d}\end{aligned}$ & $\begin{array}{c}28.3 \\
\pm 17.5_{b}\end{array}$ & $\begin{aligned} & 17.9 \\
\pm & 8.4_{\mathrm{b}, \mathrm{c}}\end{aligned}$ & $\begin{array}{l}7.1 \\
\pm \\
.7 \mathrm{~d}\end{array}$ \\
\hline$\overline{\mathrm{X}}$ no. of species & $\begin{array}{c}7.0 \\
\pm 3.0_{\mathrm{a}, \mathrm{b}}\end{array}$ & $\begin{aligned} & 8.4 \\
+ & 3.4 \mathrm{a}\end{aligned}$ & $\begin{array}{c}4.5 \\
\pm 2.2_{\mathrm{c}, \mathrm{d}}\end{array}$ & $\begin{array}{c}6.1 \\
\pm 3.2 \mathrm{~b}, \mathrm{c}\end{array}$ & $\begin{array}{c}8.1 \\
\pm 3.0_{a, b}\end{array}$ & $\begin{array}{c}4.0 \\
\pm 2.0_{\mathrm{d}}\end{array}$ \\
\hline
\end{tabular}

*Numbers of pitfall traps operational during each sample period were: each urban yard-2, Briones-3, each Tilden subsite- 2 (the catch from one Briones trap was deleted when comparing sites). 
The total numbers of spiders caught and the species represented in pitfall traps varied considerably among the study sites. At Briones, 297 spiders were collected, comprising 32 species in 11 families (see Appendix C). Numbers of spiders caught in pitfall traps at the urban yards were low; only 132 individuals were captured representing 25 species in 14 families from all three yards. From Tilden, 757 spiders from 17 families containing 45 species were collected.

One measure of similarity among the study sites was the number of spider species found in common. Only five spider species: Micaria n.sp., Psilochorus apicalis, Trachyzelotes barbartus, and two Zelotes sp. were found in the urban yards and Briones, suggesting two distinct ground-surface spider communities (see Appendix C). Tilden most closely resembled Briones in ground-surface spiders captured, sharing 15 species while sharing only 8 species with the urban yards.

\section{Visual samples}

Overall there was no clear pattern among sites for mean number of spiders per visual sample. G1 had a significantly higher mean than did Briones or Tilden; however, G2 and G3 did not. Tilden 2 had the lowest mean number of all sites, but not statistically less than $\mathrm{G} 3$, the urban garden with the lowest mean number of spiders.

TABLE 4. MOST FREQUENTLY OCCURRING SPIDER FAMILIES FROM PITFALL TRAPS AND VISUAL SAMPLES AS A PERCENTAGE OF TOTAL SAMPLES COLLECTED AT EACH STUDY SITE*

\begin{tabular}{|c|c|c|c|}
\hline \multirow[b]{2}{*}{ Family } & \multicolumn{3}{|c|}{ Percentage of spiders per family } \\
\hline & Urban & Briones & Tilden \\
\hline \multicolumn{4}{|l|}{ Pitfall traps } \\
\hline Gnaphosidae & 44 & 34 & 46 \\
\hline Agelenidae & 27 & 9 & 5 \\
\hline Lycosidae & 9 & 36 & 15 \\
\hline Linyphiidae & 5 & 1 & 1 \\
\hline Clubionidae & 6 & 9 & 18 \\
\hline Salticidae & 2 & 2 & 7 \\
\hline \multirow[t]{2}{*}{ All others } & 7 & 9 & 8 \\
\hline & 100 & 100 & 100 \\
\hline \multicolumn{4}{|l|}{ Visual samples } \\
\hline Araneidae & 34 & 53 & 26 \\
\hline Agelenidae & 26 & 24 & 25 \\
\hline Theridiidae & 6 & 8 & 4 \\
\hline Linyphiidae & 26 & 1 & 12 \\
\hline Salticidae & 1 & 5 & 6 \\
\hline Lycosidae & 2 & 4 & 9 \\
\hline \multirow[t]{2}{*}{ All others } & 5 & 5 & 12 \\
\hline & 100 & 100 & 100 \\
\hline
\end{tabular}

* Numbers of pitfall traps operational during each sample period were: each urban yard-2, Briones-3, Tilden subsite-2 (the catch from one Briones trap was deleted when comparing sites). 
Spider species diversity, from visual samples, was measured by mean number of species per sample (table 3). As was found for mean spider numbers, no pattern among sites was evident for number of spider species. G3 and Tilden 2 had the lowest means while Tilden 1 and G2 had the highest, but not significantly higher than G1 or Briones.

Total numbers of spiders seen in visual samples and their familial compositions were different among the three study sites. At Briones, the 353 spiders recorded belonged to 16 species and 10 families (see Appendix D). A combined total of 980 spiders recorded at the urban sites represented 26 species and 14 families (see Appendix D). From Tilden, the 257 spiders collected represented 26 species and 12 families. The three most commonly caught families at Berkeley's urban yards and Briones were identical, and two of these three families (Agelenidae and Theridiidae) occurred at similar frequencies (table 4). The two most frequently recorded families at Tilden were identical to those at Briones and the urban gardens, although they occurred at different frequencies.

Between Briones and all three urban yards only one visually sampled species was shared (Tibellus oblongus) (table 5). However, at least five species were common to all three urban yards. Tilden shared seven species with the urban site plus three more possible species identifiable only to genus and four species with four possible additional species were shared with Briones (see Appendix D).

The heights at which spiders were found in visual samples were grouped into three categories corresponding to the three heights at which insects were sampled with sticky boards. Percentages were calculated to indicate the total number of spiders found during the study at these heights (table 6). At all three study sites percentages of spiders decreased with height. However, the distribution of spiders was different between the urban site and either Briones or Tilden. At Briones and Tilden more than 70 percent of the spiders were found at the lowest height level, while at the urban habitat approximately 45 percent of the spiders were at this level. Only a small percentage of spiders occurred at the lowest

TABLE 5. SPIDER SPECIES FOUND IN COMMON AMONG SITES (VISUAL SAMPLES)

\begin{tabular}{lll}
\hline \hline Urban and Tilden & Urban and Briones & Tilden and Briones \\
\hline Anyphaena californica & Tibellus oblongus & Argiope trifasciata \\
Enoplognatha ovata & & Calilena stylophora \\
Evarcha hoyi & & Cyclosa turbinata \\
Hololena adnexa & Dictyna agressa \\
Microlinyphia dana & & Meteperis sp. \\
Misumenops importunus & Oxyopes sp. \\
Zygiella $x$-notata & Pardosa sp. \\
Oxyopes sp. & Phidippus sp. \\
Pardosa sp. & \\
Theridion $\mathrm{sp}$. & \\
\hline
\end{tabular}


height level for Briones and Tilden, 1.0 percent and 7.3 percent respectively. In contrast, more than 20 percent of the spiders were found at this height in the urban habitat. The percentage of spiders at the middle height level was slightly higher for urban versus nonurban habitats.

\section{Plant Structural Diversity}

Calculation of the plant-diversity index reflected combined number of plant species and amount of cover provided by each species into a single figure. A higher index was attributed to either more species or more equally distributed coverage among plant species. In the urban yards the index increased from $G 1$ to $G 3(G 1,2.9 ; G 2,3.8 ; G 3,4.1)$. By comparison, the plant-diversity index was 2.8 at Briones and 2.7 at Tilden, both lower than any urban yard. The higher index for urban yards reflects the greater number of plant species plus equitability of plant coverage. Greater diversity of plant species can be directly attributed to home owners who prefer yards with a mixture of different plants. In contrast, the native habitat is more limited in plant diversity, and Avena and Bromus grass species dominated most of the available space, which effectively lowered the plant-diversity index. Similar dominance of grass species at Tilden resulted in a low plant-diversity index, even though Tilden had more plant species than Briones.

Vertical distribution of vegetation was calculated as two different percentages: amount of plant cover at each individual level and amount of vegetation present at one level as a percentage of total vegetation of all three levels. At urban yards plant cover was greatest at level 3 and decreased with height (table 7). Plant cover also decreased with height at Briones and there was less coverage at levels 1 and 2 compared with the urban yards. Plant coverage at Tilden was most similar to the urban yards.

TABLE 6. PERCENTAGES OF SPIDERS FOUND IN VISUAL SAMPLES AT THREE HEIGHT LEVELS IN URBAN YARDS, BRIONES, AND TILDEN

\begin{tabular}{lccc}
\hline \hline Height level & Urban & Briones & Tilden \\
\hline & $(\%)$ & $(\%)$ & $(\%)$ \\
Level $1(168 \mathrm{~cm})$ & 20.7 & 1.0 & 7.3 \\
Level $2(137 \mathrm{~cm})$ & 33.7 & 26.0 & 21.3 \\
Level $3(46 \mathrm{~cm})$ & 45.6 & 73.0 & 71.4 \\
\hline
\end{tabular}

TABLE 7. PERCENT VEGETATIVE COVER AND PERCENT TOTAL VEGETATION AT THREE HEIGHT LEVELS IN URBAN YARDS, BRIONES, AND TILDEN

\begin{tabular}{lccc}
\hline \hline & \multicolumn{3}{c}{ Percent cover and (total vegetation) } \\
\cline { 2 - 4 } Height level & Urban & Briones & Tilden \\
\hline & $(\%)$ & $(\%)$ & $(\%)$ \\
Level $1(168 \mathrm{~cm})$ & $11.4(11.5)$ & $0.5(0.4)$ & $6.6(17.0)$ \\
Level $2(137 \mathrm{~cm})$ & $16.0(41.9)$ & $10.2(22.0)$ & $7.2(25.5)$ \\
Level $3(46 \mathrm{~cm})$ & $27.1(46.2)$ & $33.3(77.0)$ & $29.5(57.2)$ \\
\hline
\end{tabular}


Differences in distribution of total vegetation were found among the urban yards, Briones, and Tilden. In urban yards levels 2 and 3 were almost equal in percentage of total vegetation with level 1 markedly lower (table 7). At Briones, more than 70 percent of the vegetation was at level 3, the lowest height. Levels 1 and 2 were both lower in percent total vegetation than those at urban yards. Plant coverage at Tilden was most similar to the urban site (table 7). However, distribution of the vegetation more closely resembled Briones, where over 59 percent of the vegetation was at the lowest level.

Spatial organization of vegetation among the sites, as indexed by the ratio of vertically to horizontally positioned plant structures, was distinctly different. As mentioned previously, a value less than 1.0 indicates a high percentage of horizontally oriented vegetation, while a value greater than 1.0 represents a high percentage of vertically oriented vegetation. At the urban yards vertical/horizontal ratios were: G1, 0.53; G2, 0.73; and G3, 0.69 for a mean value of 0.65 . For Briones, the ratio was more than three times the value found at any urban site, 2.58 , indicating a high proportion of vertically oriented vegetation. An intermediate value of 1.6 was calculated for Tilden for vegetation tended to be vertically oriented, influenced by several species of grasses.

Vegetation architecture of each plant species at a site was graphed according to the method of Curtis and Bignal (1978). Graphing illustrated the vertical and horizontal orientation of a plant's parts; representative plants of each site are shown in figure 4 . Number of vertical plant parts per sample height occur on the left side of the vertical bar and number of horizontal plant parts on the right, where horizontal length of a triangle represents the number of plant parts at the sample height.

Certain trends emerged from graphing all plant species in each habitat type. Plant architecture at Briones tended to be vertical. The abundance of low-growing grasses at this site heavily influenced the structural architecture from ground level to one meter. Although these same grasses occurred at Tilden, their influence on total plant architecture was somewhat lessened by the contributions of other plants at low heights. Above the height of grasses at Tilden, plant architecture closely resembled the urban habitat where the variety of plant species provided more equity between vertical and horizontal plant structures.

While the tendency towards vertical plant structure and decreased heterogeneity of vegetation occurs at Briones, two plants (Baccharis pilularis and Lupinus albifrons) possessed structures suitable for some web-building spiders. Cyclosa turbinata and Tetragnatba laboriosa were commonly found on these plants. However, from ground level to 1 meter in height only one orb-weaving spider, Argiope trifasciata, was repeatedly found.

Reduced structural diversity resulted in low web-building spider diversity above ground level and these spiders tended to be more abundant at or below ground level. Plant architecture at ground level was utilized by two web-building spiders: Latrodectus besperus and Calilena stylophora. These spiders do not construct orbs, but rather three dimensional structures that may use nearby plant structures for support. For example, $L$. besperus constructs its web within available holes or crevices in the soil. The tangled crosslines of this theridiid web often extend above ground level connected to adjacent plants. These webs tend to catch surface-moving arthropods. The $C$. stylophora web is similar in extending below surface level, but the catching portion of the web exists as a sheet web on the soil surface. Like many other agelenid webs, short trip lines rise above the web attached to plants. The portion of the web below the soil is a funnel-shaped retreat where the spider resides waiting for prey. 


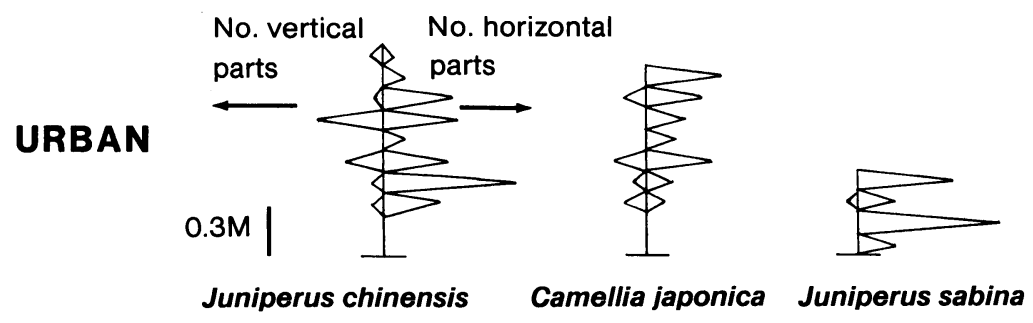

BRIONES

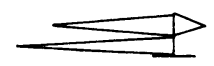

Melilotus indica

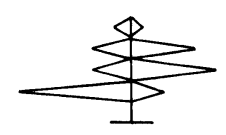

Baccharis pilularis

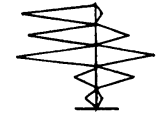

Lupinus albifrons

TILDEN

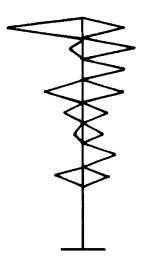

Quercus agrifolia

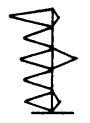

Avena fatua

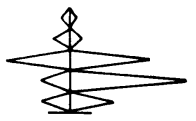

Tamarix pentandra

Fig. 4. Schematic representation of vertical and horizontal vegetation of selected plant species from study sites. (See text for further explanation.)

Plants at the urban habitat had a more heterogeneous combination of plant forms. The greater balance between horizontal and vertical structures creates a more varied spatial diversity and therefore an increased number of possible microhabitats. The diversity of microhabitats was evident in the higher incidence of spider species within the vegetation. Not only were numbers of individuals greater, but so was variety of lifestyles. For example, vagrant spiders, like clubionids, anyphaenids, and gnaphosids, were found above ground level, as were active hunting (salticids and oxyopids) and sit-and-wait (thomisiids) spiders. Most dramatic was the number of different kinds of web-building spiders. Predominant among the web builders were Linyphiidae and Theridiidae, accounting for 30 percent of 
the total number of species in visual samples at the urban habitat. In particular, Neriene digna (Linyphiidae) and Theridion sp. (Theridiidae) were found in every visual sample.

Identical plant species from different sites retained one particular structural form. In addition, spiders that built on a plant from one location would also choose to build on this species at other sites. For example, Argiope trifasciata built its web exclusively on dried grasses at both Tilden and Briones. Hololena adnexa was seen predominately on Juniperus sabina 'Tamariscifolia' at Tilden, a preferred plant in urban areas. Dictyna agressa built its web in grass heads and on Baccharis seedlings, both at Tilden and Briones. This suggests that some spider species prefer and search out particular plant species or plant structures on which to build a web, regardless of site.

\section{Urban Surveys}

The urban survey indicated the numbers and kinds of ornamental plants (woody and herbaceous) grown in the San Francisco Bay Area and also the numbers and kinds of spiders associated with this habitat. The total number of ornamental plant species in the six cities surveyed (Oakland, Berkeley, Burlingame, El Cerrito, Orinda Village, and San Rafael) ranged from 53 to 79 . Each yard averaged from 6.6 to 8.7 plant species with a range from 2 to 15 species. All plants found in the three Berkeley urban yards were present in at least one yard of another city. Therefore, the yards in this study were typical of the yards surveyed from other cities in number and species of plants.

The frequencies and species of spiders found in the survey varied little from city to city. The mean number of spider species found per yard ranged from 2.3 to 3.5. Actual numbers were from none to six species per yard. Several species not found in the Berkeley urban study sites but found at Briones or Tilden were occasionally found in surveyed yards. These species included: Latrodectus besperus, Cyclosa turbinata, Argiope trifasciata, and Calilena stylophora. Other species not collected at any experimental site were found during the survey; however, these spiders occurred infrequently with a spotty distribution.

A general trend was observed in the relationship between number of plants in a yard and number of spiders found. An increase in the number of plants coincided with a greater number of spiders. However, there were instances where few spiders were seen in yards with a high diversity of plants. Other factors probably become important modifiers of this relationship. For example, yard owners manipulate the habitat through regular maintenance.

Yard maintenance activity was qualitatively measured for the three yards comprising the Berkeley urban habitat. Activity ranged from only watering a tree once a week (G1) to daily watering, pruning, raking, etc. (G3). Owner yard maintenance at G2 was intermediate between these two extremes. It is of interest that ground-surface spider numbers and number of species decreased with increasing yard maintenance. Qualitative estimation of yard care in surveyed yards (with G1, G2, and G3 as standards) occurred with equal representation of each yard maintenance type. Therefore, a range in maintenance from very little to daily care allows for the possibility of yard owner influence on spider numbers. Maintenance often includes spraying of pesticides, which was repressed in the Berkeley yards. It is highly possible that a home owner will be prone to spray pesticides if he/she has planted a more diverse garden. This may account for low numbers of spiders in a yard with high plant diversity. 


\section{Correlation Coefficients}

Pearson correlation coefficients were calculated with the SPSS statistical program for the following variables: pitfall trap insect morpho-species, pitfall trap insect numbers, pitfall trap spider species, pitfall trap spider numbers, visual spider numbers, visual spider species numbers, sticky board insect numbers, sticky board insect morpho-species, weekly mean temperatures, and weekly mean relative humidities. Every possible paired combination was calculated, but no consistent correlations were found for any sites. Cherrett (1964) reported a positive linear correlation between mean numbers of spiders and other arthropods per square meter; however, Turnbull (1966) found no correlation between insect abundance and spider abundance. Similarly, prey availability showed no correlation with web-building spider species diversity in a California or a Costa Rica meadow and shrub habitat (Greenstone 1984). It is possible that if a more exhaustive sampling scheme or a concentrated effort on just one or two microhabitats had been performed there may have been a correlation between insect and spider numbers.

\section{DISCUSSION}

Several authors have shown a correlation between plant structure and preference by different animal species (MacArthur and MacArthur 1961; Pianka 1966), including spiders (Greenquist and Rover 1976; Hatley and MacMahon 1980; Robinson 1981; Abraham 1983). The major factor influencing aerial spiders in this study was plant structural diversity, which provides areas with different temperatures, relative humidities, light intensities, and structural complexities (Duffey 1962). The relationship between plant structure and aerial spiders was evident when comparing plant characteristics for each site with the resident aerial spiders. Considering all three study sites, the greatest number and species of aerial spiders were found at the urban gardens, where the higher plant diversity index indicated a greater number of plant types and vegetation forms. In addition, vegetation was more equitably distributed between vertical and horizontal planes, thereby enhancing the quantity of microhabitats available to spider species. Further evidence of plant form affecting spider-species community composition was seen where the percentage of spiders found at three height levels increased with greater vegetation cover and greater total vegetation. The influence of vegetation structure on urban spider communities would be further clarified by experimentally manipulating vegetation as was done by Hatley and MacMahon (1980) for a big sage community.

In contrast to the urban site, the small amount of plant structural diversity at Briones limited its diversity of aerial spiders. Vegetation was oriented primarily in a vertical plane due not only to annual grasses, but to Baccharis and Lupinus as well. Despite plant structures available for web building, few aerial spiders made use of them. The climate at Briones may explain the low numbers of aerial spiders and will be discussed later.

The number of plant species and accompanying complexity of plant structures at Tilden were most similar to the urban yards. They both had a high diversity of plant species and the spatial orientation of the vegetation was nearly equally distributed between the vertical and horizontal planes. However, the vegetation at ground level was most similar to Briones. Therefore, structural characteristics of the Tilden habitat were due to a mixture 
of both native and ornamental plants. The intermediate character of Tilden's flora also influenced its spider community. Tilden shared the most aerial spider species with the urban habitat and the most ground-surface spider species with Briones.

The climate in the urban yards was favorable to aerial spiders. Moderate temperatures, lower local winds due to enclosed yards, and higher humidities all helped decrease the risk of desiccation aerial spiders are exposed to in vegetation. Muma (1973) found that moderate temperatures and higher humidities were conducive to the presence of Theridiidae and Linyphiidae. In this study, these two spider families also had the greatest number of species for urban aerial spiders. Another proposed influence on greater prevalence of small web-building spiders in urban habitats was the attraction of small flying insects to artificial light (Muma 1973; Vincent and Frankie 1985).

Vegetation structure and its associated microclimate influence spider community structure (Duffey 1962). Susceptibility to desiccation for aerial spiders depends, in part, on the plant communities present in a habitat. Because plant density was low and plant forms more open at Briones, spiders living on these plants would be more exposed to wind and drier air and thus desiccation. Therefore, it is likely that higher temperatures and lower humidities prevented some spiders from surviving on these plants. The sparse amount of ground cover combined with this climate also may have influenced the ground-spider community. Specialization to these climatic conditions may explain why there was only one species at Briones representative of each of the three most common families: Lycosidae, Agelenidae, and Theridiidae.

Microhabitats at Tilden were diversified by the wider range of temperatures and humidities, creating areas from dry and hot to humid and cool. This may account for the greater numbers and species of ground-surface spiders found here. However, it appears that the open structure of the plant community subjected aerial spiders to greater chance of desiccation, similar to Briones. Only those areas lower to the ground and less subject to desiccation factors were favorable to aerial spiders. Indeed, most aerial spider species shared with the urban gardens built their webs close to the ground. These spiders, either through their adaptive ability or preadaptive traits, such as preferring cooler wetter habitats, have been able to succeed in variable urban environments and seem just as successful at Tilden.

Owner manipulation of urban yards reduced not only the total number of spiders collected in a yard, but the number of spider species as well. Changing the ground surface habitat by tilling, watering, fertilizing, etc. strongly altered the composition of the groundsurface spider community. Muma (1973) suggested that low numbers of ground-surface spiders found in a Florida citrus grove may have been due to regular tilling of the soil. Although spiders in urban areas may be more tolerant of disturbance (Davis 1979), there does exist a variation in tolerance among spiders. For example, the only trap-door spider collected at the urban site was in the yard with essentially no soil disturbance. In addition, there was a direct negative correlation between the amount of disturbance recorded for a yard and the number of individuals and species of spiders collected at surface level. Although other factors may also influence the presence or absence of particular spider species at ground level, it appears that in urban areas owner manipulation does adversely affect some spiders. 


\section{SUMMARY}

Three habitats, urban, native, and semi-native, were studied to determine the species composition of their spider communities and examine abiotic and biotic factors that may influence spider community composition. The spider community at the urban habitat consisted primarily of aerial spider species. Their abundance was attributed to diversity of plant species and the numerous microhabitats associated with them. High humidities and moderate temperatures also seem to favor selected urban spider species. The small numbers of ground-surface spiders were due to human manipulation of the yards at ground level. In contrast to the urban spider community, Briones Reservoir, a disturbed chaparral habitat, was dominated by ground-surface species. The small amount of plant diversity, limited plant structural diversity, the associated lack of microhabitat diversity, and the hotter and drier climate all contributed to the restriction of aerial spider species at Briones. Abundance of ground-surface spiders was probably due to high numbers of insect prey, although spider diversity may have been restricted by climate. Tilden, a semi-native habitat, had a ground-surface spider community similar to Briones and an aerial spider community most closely resembling the urban habitat. The overall higher spider diversity may be attributed to a high diversity of plant species and, consequently, a higher microhabitat diversity. Tilden's climate, with a wide range in humidity and temperature, also helped diversify the microhabitat.

\section{ACKNOWLEDGMENTS}

Our deepest gratitude to the following people for their assistance in identification of specimens: W. J. Gertsch, N. I. Platnick, A. F. Millidge, C. E. Griswold, E. I. Schlinger, and V. D. Roth. We would also like to thank the East Bay Municipal Water District and Tilden Regional Park for access to and use of their property for this research. Finally, thanks go to Professors E. I. Schlinger and H. Baker for comments. on this manuscript. This research was supported in part by the California Agricultural Experiment Station and grants from Sigma Xi.

APPENDIX A

NUMBERS OF FAMILIES AND MORPHO-SPECIES OF INSECTS SAMPLED FROM STICKY BOARDS AT URBAN YARDS, BRIONES, AND TILDEN*

\begin{tabular}{|c|c|c|c|}
\hline \multirow[b]{2}{*}{ Order } & \multicolumn{3}{|c|}{ No. of families and (morpho-species) } \\
\hline & Urban & Briones & Tilden \\
\hline Diptera & $16(25)$ & $13(23)$ & $21 \quad(36)$ \\
\hline Hymenoptera & $9(29)$ & $15(36)$ & $20(63)$ \\
\hline Coloptera & $8(20)$ & $10(12)$ & $13(26)$ \\
\hline Homoptera & $6(10)$ & $316)$ & $6(10)$ \\
\hline Hemiptera & $3(4)$ & $3(4)$ & $4 \quad(6)$ \\
\hline Thysanoptera & $2(2)$ & 1 (1) & (2) \\
\hline Neuroptera & 1 (1) & 1 (1) & (2) \\
\hline Pscoptera & 1 (1) & $1(1)$ & 1 (1) \\
\hline Lepidoptera & 1 (1) & 1 (1) & 1 (1) \\
\hline \multirow[t]{2}{*}{ Ephemeroptera } & $1(1)$ & 1 (1) & - \\
\hline & $\overline{48(94)}$ & $49(86)$ & $70(147)$ \\
\hline
\end{tabular}

*Numbers of sticky boards at a site were: each urban yard, 3; Briones, 3; and each Tilden subsite, 3. 
APPENDIX B

NUMBERS OF FAMILIES AND MORPHO-SPECIES OF INSECTS SAMPLED IN PITFALL TRAPS AT URBAN YARDS, BRIONES, AND TILDEN*

\begin{tabular}{|c|c|c|c|}
\hline \multirow[b]{2}{*}{ Order } & \multicolumn{3}{|c|}{ No. of families and (morpho-species) } \\
\hline & Urban & Briones & Tilden \\
\hline Diptera & $15(24)$ & $10(15)$ & $13(23)$ \\
\hline Hymenoptera & $7(10)$ & $11(16)$ & $13(18)$ \\
\hline Coloptera & $9(32)$ & $10(33)$ & $14(38)$ \\
\hline Homoptera & $2(8)$ & $2(3)$ & 4 (16) \\
\hline Hemiptera & $1(2)$ & $1(2)$ & $2 \quad(2)$ \\
\hline Thysanoptera & 1 (1) & 1 (1) & (1) \\
\hline Collembola & $3(3)$ & - & (3) \\
\hline Pscoptera & $2(2)$ & $2(2)$ & $2 \quad(2)$ \\
\hline Lepidoptera & $3(3)$ & $3(2)$ & - \\
\hline Thysanura & - & $2(2)$ & $2 \quad(2)$ \\
\hline Orthoptera & 1 (2) & 1 (1) & $2 \quad(3)$ \\
\hline Dermaptera & 1 (1) & 1 (1) & - \\
\hline Isoptera & - & - & $1 \quad$ (1) \\
\hline \multirow[t]{2}{*}{ Embioptera } & - & - & (1) \\
\hline & $45(88)$ & $44(78)$ & $58(110)$ \\
\hline
\end{tabular}

*Numbers of pitfall traps operational during each sample period were: each urban yard, 2; Briones, 3; each Tilden subsite, 2 (the catch from one Briones trap was deleted when comparing sites).

\section{APPENDIX C}

SPIDER TAXA CAUGHT IN PITFALL TRAPS AT THE URBAN YARDS, BRIONES, AND TILDEN

\begin{tabular}{|c|c|c|c|}
\hline Spider taxa & Urban & Briones & Tilden \\
\hline \multicolumn{4}{|l|}{ Agelenidae } \\
\hline Blabomma california (Simon) & $\mathbf{x}$ & & \\
\hline Calilena stylophora Chamberlin \& Ivie & & $\mathbf{x}$ & $\mathbf{x}$ \\
\hline Calymmaria california (Banks) & $\mathbf{x}$ & & $\mathbf{x}$ \\
\hline Cybaeus adenes Chamberlin \& Ivie & & & $\mathbf{x}$ \\
\hline Hololena adnexa (Chamberlin \& Gertsch) & $\mathbf{x}$ & & \\
\hline \multicolumn{4}{|l|}{ Amaurobiidae } \\
\hline Pimus sp. & & & $\mathbf{x}$ \\
\hline Walmus sp. & & & $\mathbf{x}$ \\
\hline \multicolumn{4}{|l|}{ Anyphaenidae } \\
\hline Anyphaena californica (Banks) & $\mathbf{x}$ & & \\
\hline \multicolumn{4}{|l|}{ Clubionidae } \\
\hline Castianeira floridana (Banks) & & $\mathbf{x}$ & $\mathbf{x}$ \\
\hline Liocranoides sp. & & $\mathbf{x}$ & $\mathbf{x}$ \\
\hline Micaria new sp. & $\mathbf{x}$ & $\mathbf{x}$ & $\mathbf{x}$ \\
\hline Phrurotimpus parallelus (Chamberlin) & & $\mathbf{x}$ & \\
\hline Scotinella californica (Chamberlin \& Gertsch) & & $\mathbf{x}$ & $\mathbf{x}$ \\
\hline Scotinella sp. & & $\mathbf{x}$ & \\
\hline Tracbelas sp. & $\mathbf{x}$ & & \\
\hline \multicolumn{4}{|l|}{ Cterizidae } \\
\hline Actinoxia sp. & & & $\mathbf{x}$ \\
\hline Apositchus atomarius Simon & & & $\mathbf{x}$ \\
\hline Promyrekiaphila gertschi (Schenkel) & $\mathbf{x}$ & & \\
\hline
\end{tabular}


APPENDIX C (continued)

\begin{tabular}{|c|c|c|c|}
\hline Spider taxa & Urban & Briones & Tilden \\
\hline \multicolumn{4}{|l|}{ Dictynidae } \\
\hline Dictyna agressa (Ivie) & $\mathbf{x}$ & & $\mathbf{x}$ \\
\hline Dictyna serena Chamberlin \& Gertsch & & & $\mathbf{x}$ \\
\hline Tricholatbys bansii (Schenkel) & & $\mathbf{x}$ & $\mathbf{x}$ \\
\hline \multicolumn{4}{|l|}{ Dipluridae } \\
\hline Calisoga longitarsis Simon & & & $\mathbf{x}$ \\
\hline \multicolumn{4}{|l|}{ Erigonidae } \\
\hline Ceraticelus sp. & & & $\mathbf{x}$ \\
\hline Erigone dentosa O. P. Cambridge & $\mathbf{x}$ & & \\
\hline Erigone n. sp. & $\mathbf{x}$ & & \\
\hline Erigone sp. & $\mathbf{x}$ & & \\
\hline \multicolumn{4}{|l|}{ Gnaphosidae } \\
\hline Drassyllus insularis (Banks) & & $\mathbf{x}$ & $\mathbf{x}$ \\
\hline Drassyllus lamprus (Chamberlin) & & $\mathbf{x}$ & \\
\hline Drassyllus saphes Chamberlin & & $\mathbf{x}$ & $\mathbf{x}$ \\
\hline Haplodrassus signifer (C. L. Koch) & & $\mathbf{x}$ & \\
\hline Sergiolus montanus (Emerton) & & & $\mathbf{x}$ \\
\hline Tracbyzelotes barbatus (L. K.) & $\mathbf{x}$ & $\mathbf{x}$ & $\mathbf{x}$ \\
\hline Zelotes antberus Chamberlin & & $\mathbf{x}$ & \\
\hline Zelotes discens Chamberlin & & & $\mathbf{x}$ \\
\hline Zelotes puritanus (Chamberlin) & & $\mathbf{x}$ & $\mathbf{x}$ \\
\hline Zelotes sp. 2 & $\mathbf{x}$ & $\mathbf{x}$ & $\mathbf{x}$ \\
\hline Zelotes sp. 3 & & $\mathbf{x}$ & \\
\hline Zelotes sp. 4 & $\mathbf{x}$ & $\mathbf{x}$ & $\mathbf{x}$ \\
\hline Zelotes sp. 5 & & $\mathbf{x}$ & \\
\hline Zelotes sp. 6 & & & $\mathbf{x}$ \\
\hline Zelotes sp. 7 & & & $\mathbf{x}$ \\
\hline Zelotes sp. 8 & & & $\mathbf{x}$ \\
\hline Zelotes sp. 9 & & & $\mathbf{x}$ \\
\hline \multicolumn{4}{|l|}{ Linyphiidae } \\
\hline Leptbyphantes tenuis (B. L.) & $\mathbf{x}$ & & \\
\hline Meioneta sp. 1 & & $\mathbf{x}$ & \\
\hline Meioneta sp. 2 & & $\mathbf{x}$ & $\mathbf{x}$ \\
\hline Tennesseellum formicum (Emerton) & & $\mathbf{x}$ & \\
\hline \multicolumn{4}{|l|}{ Lycosidae } \\
\hline Pardosa californica Keyserling & $\mathbf{x}$ & & \\
\hline Pardosa ramulosa (McCook) & $\mathbf{x}$ & & \\
\hline Pardosa tuoba Chamberlin & $\mathbf{x}$ & & $\mathbf{x}$ \\
\hline Schizocosa mcCookii (Montgomery) & & $\mathbf{x}$ & $\mathbf{x}$ \\
\hline Tarantula kochii Keyserling & & & $\mathbf{x}$ \\
\hline \multicolumn{4}{|l|}{ Mimetidae } \\
\hline Mimetus hesperus Chamberlin & & $\mathbf{x}$ & $\mathbf{x}$ \\
\hline \multicolumn{4}{|l|}{ Nesticidae } \\
\hline Eidmanella pallida (Emerton) & $\mathbf{x}$ & & \\
\hline \multicolumn{4}{|l|}{ Oecobiidae } \\
\hline Oecobius annulipes Lucan & $\mathbf{x}$ & & \\
\hline \multicolumn{4}{|l|}{ Oxyopidae } \\
\hline Oxyopes salticus Hentz & & & $\mathbf{x}$ \\
\hline \multicolumn{4}{|l|}{ Philodromidae } \\
\hline Ebo merkerli Schick & & & $\mathbf{x}$ \\
\hline
\end{tabular}


APPENDIX C(continued)

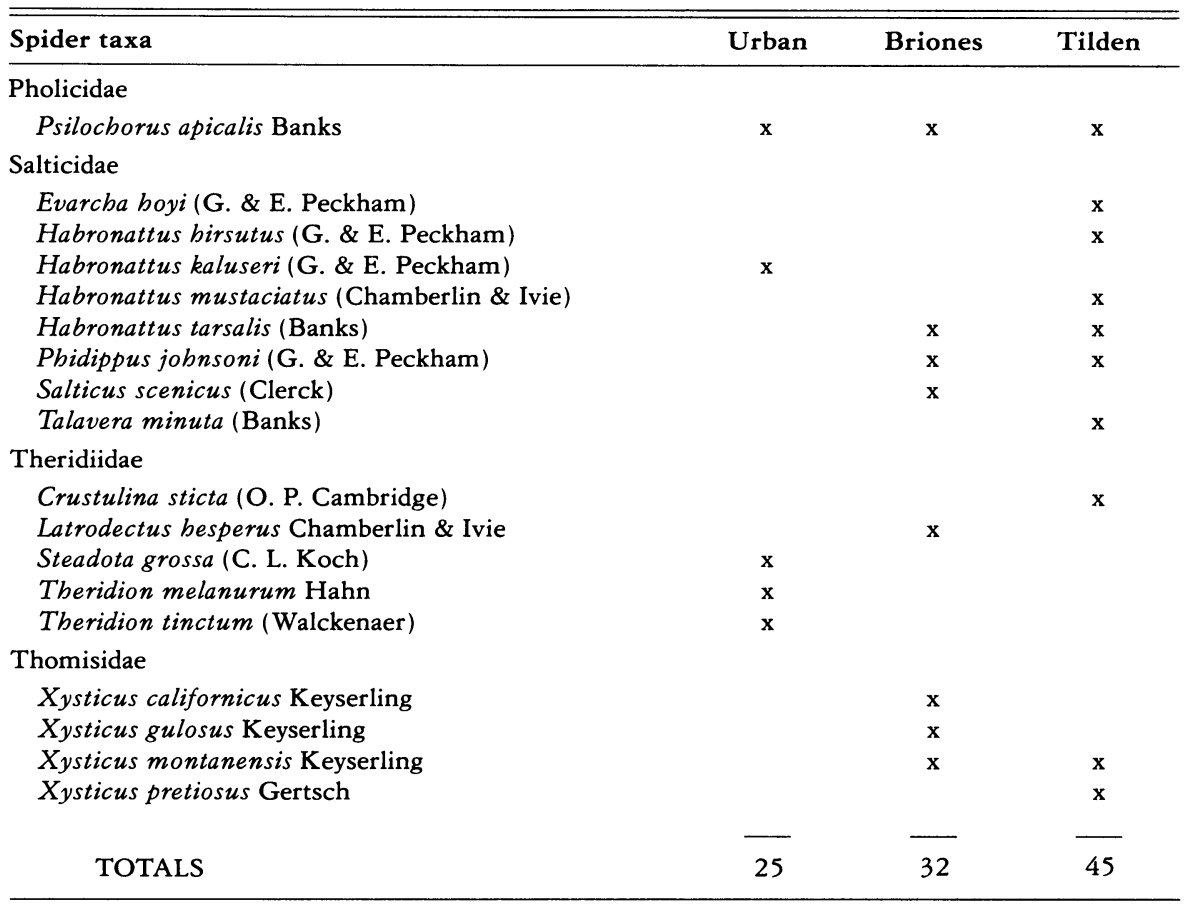

\section{APPENDIX D}

SPIDER TAXA OBSERVED (VISUAL SAMPLE) AT THE URBAN YARDS, BRIONES, AND TILDEN

\begin{tabular}{|c|c|c|c|}
\hline Spider taxa & Urban & Briones & Tilden \\
\hline \multicolumn{4}{|l|}{ Agelenidae } \\
\hline Calilena stylophora Chamberlin \& Ivie & & $\mathbf{x}$ & $\mathbf{x}$ \\
\hline Calymmaria sp. & $\mathbf{x}$ & & \\
\hline Hololena adnexa (Chamberlin \& Gertsch) & $\mathbf{x}$ & & $\mathbf{x}$ \\
\hline \multicolumn{4}{|l|}{ Amaurobiidae } \\
\hline Amaurobius sp. & $\mathbf{x}$ & & \\
\hline \multicolumn{4}{|l|}{ Anyphaenidae } \\
\hline Anyphaena californica (Banks) & $\mathbf{x}$ & & $\mathbf{x}$ \\
\hline Anyphaena sp. & $\mathbf{x}$ & & \\
\hline \multicolumn{4}{|l|}{ Araneidae } \\
\hline Araneus andrewski (Archer) & & & $\mathbf{x}$ \\
\hline Araneus diadematus Clerck & $\mathbf{x}$ & & \\
\hline Araneus sp. & & & $\mathbf{x}$ \\
\hline Argiope trifasciata (Forskal) & & $\mathbf{x}$ & $\mathbf{x}$ \\
\hline Cyclosa turbinata (Walckenaer) & & $\mathbf{x}$ & \\
\hline Metepeira gosoga Chamberlin \& Ivie & & $\mathbf{x}$ & \\
\hline Metepeira sp. & & & $\mathbf{x}$ \\
\hline Neoscona arabesca (Walckenaer) & & & $\mathbf{x}$ \\
\hline Zygiella $x$-notata (Clerck) & $\mathbf{x}$ & & $\mathbf{x}$ \\
\hline
\end{tabular}


APPENDIX D (continued)

\begin{tabular}{|c|c|c|c|}
\hline Spider taxa & Urban & Briones & Tilden \\
\hline \multicolumn{4}{|l|}{ Clubionidae } \\
\hline Chiracantbium inclusum (Hentz) & $\mathbf{x}$ & & \\
\hline \multicolumn{4}{|l|}{ Dictynidae } \\
\hline Dictyna agressa (Ivie) & & $\mathbf{x}$ & $\mathbf{x}$ \\
\hline \multicolumn{4}{|l|}{ Erigonidae } \\
\hline Ceraticelus sp. & & & $\mathbf{x}$ \\
\hline \multicolumn{4}{|l|}{ Gnaphosidae } \\
\hline Agroeca sp. & $\mathbf{x}$ & & \\
\hline Poecilochroa sp. & & & $\mathbf{x}$ \\
\hline Sergiolus montanus (Emerton) & & & $\mathbf{x}$ \\
\hline Strotarcbus sp. & $\mathbf{x}$ & & \\
\hline Zelotes sp. & $\mathbf{x}$ & & \\
\hline \multicolumn{4}{|l|}{ Linyphiidae } \\
\hline Batbyphantes sp. 1 & $\mathbf{x}$ & & \\
\hline Batbyphantes sp. 2 & $\mathbf{x}$ & & \\
\hline Centromerus sp. & & & $\mathbf{x}$ \\
\hline Leptbyphantes tenuis (B.L.) & $\mathbf{x}$ & & \\
\hline Microlinyphia dana (Chamberlin \& Ivie) & $\mathbf{x}$ & & $\mathbf{x}$ \\
\hline Neriene dana (Keyserling) & $\mathbf{x}$ & & $\mathbf{x}$ \\
\hline \multicolumn{4}{|l|}{ Lycosidae } \\
\hline Pardosa tuoba Chamberlin & & & $\mathbf{x}$ \\
\hline Pardosa sp. & $\mathbf{x}$ & $\mathbf{x}$ & \\
\hline \multicolumn{4}{|l|}{ Oecobiidae } \\
\hline Oecobius annulipes Lucan & $\mathbf{x}$ & & \\
\hline \multicolumn{4}{|l|}{ Oxyopidae } \\
\hline Oxyopes salticus Hentz & & & $\mathbf{x}$ \\
\hline Oxyopes scalaris Hentz & $\mathbf{x}$ & & \\
\hline Oxyopes sp. & & $\mathbf{x}$ & \\
\hline \multicolumn{4}{|l|}{ Philodromidae } \\
\hline Tibellus oblongus (Walckenaer) & $\mathbf{x}$ & $\mathbf{x}$ & \\
\hline \multicolumn{4}{|l|}{ Salticidae } \\
\hline Evarcba boyi (G. \& E. Peckham) & $\mathbf{x}$ & & $\mathbf{x}$ \\
\hline Habronattus sp. & & $\mathbf{x}$ & \\
\hline Metaphidippus aeneolus (Curtis) & & $\mathbf{x}$ & \\
\hline Metaphidippus barfordi (G. \&. E. Peckham) & $\mathbf{x}$ & & \\
\hline Metaphidippus imperialus (G. \& E. Peckham) & & $\mathbf{x}$ & \\
\hline Phidippus sp. & & $\mathbf{x}$ & $\mathbf{x}$ \\
\hline \multicolumn{4}{|l|}{ Tetragnathidae } \\
\hline Tetragnatba laboriosa Hentz & & $\mathbf{x}$ & \\
\hline \multicolumn{4}{|l|}{ Theridiidae } \\
\hline Acbaearanea canionis (Chamberlin \& Gertsch) & & & $\mathbf{x}$ \\
\hline Crustulina sticta (O. P. Cambridge) & & & $\mathbf{x}$ \\
\hline Enoplognatba ovata (Clerck) & $\mathbf{x}$ & & $\mathbf{x}$ \\
\hline Latrodectus besperus Chamberlin \& Ivie & & $\mathbf{x}$ & \\
\hline Theridion melanurum Hahn & $\mathbf{x}$ & & \\
\hline Theridion neomexicanum Banks & $\mathbf{x}$ & & $\mathbf{x}$ \\
\hline Theridion rabuni Chamberlin \& Ivie & & $\mathbf{x}$ & \\
\hline Theridion tinctum (Walckenaer) & $\mathbf{x}$ & & \\
\hline
\end{tabular}


APPENDIX D (continued)

\begin{tabular}{|c|c|c|c|}
\hline Spider taxa & Urban & Briones & Tilden \\
\hline \multicolumn{4}{|l|}{ Thomisidae } \\
\hline $\begin{array}{l}\text { Misumenops aikoae Schick } \\
\text { Misumenops importunus importunus (Keyserling) } \\
\text { Xysticus sp. }\end{array}$ & $\mathbf{x}$ & $\mathbf{x}$ & $\begin{array}{l}\mathbf{x} \\
\mathbf{x}\end{array}$ \\
\hline TOTALS & 27 & 16 & 26 \\
\hline
\end{tabular}

\section{LITERATURE CITED}

ABRAHAM, B. J.

1983. Spatial and temporal patterns in a sagebrush steppe spider community (Arachnida: Araneae). J. Arach. 11:31-50.

CHERRETT, J. M.

1964. The distribution of spiders on the Moor House National Reserve, Westmoreland. J. Anim. Ecol. $33: 27-48$.

CULIN, J. D., and W. RUST

1980. Comparison of the ground surface and foliage dwelling spider communities in a soybean habitat. Environ. Entomol. 9:577-82.

CURTIS, D. J., and B. BIGNAL

1978. A vertical quadrant method of describing vegetation structure. Res. and Tech. Notes S.W. Region Scotland No. 2.

DAVIS, B. N. K.

1979. The ground arthropods of London gardens. The London Nat. 58:15-24.

DUFFEY, E.

1962. A population study of spiders in limestone grassland. Description of study area, sampling methods and population characteristics. J. Anim. Ecol. 31:571-99.

1974. Habitat selection by spiders in man-made environments. Proc. Gth Int. Arachn. Congr. pp. 51-67.

FRANKIE, G. W., and C. KOEHLER

1980. Perspectives in Urban Entomology. New York: Academic Press.

FRASER, J. B.

1983. Ecological and Biological Studies on Urban and Rural Spiders, Especially on Hololena adnexa (Araneae: Agelenidae). Ph.D. Thesis, Univ. Calif., Berkeley.

GILL, D., and P. BONNETT

1973. Nature in the Urban Landscape. A study of City Ecosystems. Baltimore and New York: York Press, Inc. pp. 36-57.

GREENQUIST, E. A., and J. S. ROVER

1976. Lycosid spiders on artificial foliate: stratum choice, orientation preference, and prey wrapping. Psyche, July. pp. 196-209.

GREENSLADE, P. J. M.

1964. Pitfall trapping as a method for studying populations of Carabidae (Coleoptera). J. Anim. Ecol. 33:301-10.

GREENSTONE, M. H.

1984. Determinants of web spider species diversity vs. prey availability. Oecologia. 62:299-304.

HATLEY, C. L., and J. A. MacMAHON

1980. Spider community organization: seasonal variation and the role of vegetation architecture. Environ. Entomol. 9:632-39.

HAWKSWORTH, D. L. (ed.)

1974. The Changing Flora and Fauna of Britain. Systematics Assoc. Special Vol. No. 6. London: Academic Press. pp. 7-26.

KASTON, B. J.

1983. Synanthropic spiders. Urban Entomology: Interdisciplinary Perspectives. G. W. Frankie and C. S. Koehler (eds.). New York: Praeger Press. pp. 221-45.

LANDSBERG, H. E.

1981. The Urban Climate. New York: Academic Press. pp. 83.

LOWRIE, D. C.

1948. The ecological succession of spiders of the Chicago area dunes. Ecology 29:334-51. 
LUBIN, V. D.

1978. Seasonal abundance and diversity of web-building spiders in relation to habitat structure on Barro Colorado Island, Panama. J. Arach. 6:31-52.

MacARTHUR, R. H., and J. W. MacARTHUR

1961. On bird species diversity. Ecology 42:594-98.

MUMA, M. H.

1973. Comparison of ground surface spiders in four central Florida ecosystems. Florida Entomol. 56:173-96.

MUNZ, P. A.

1968. A California Flora and Supplement. Berkeley: Univ. Calif. Press. p. 17.

MURDOCH, W. W., F. C. EVANS, and C. H. PETERSON

1972. Diversity and pattern in plants and insects. Ecology 53:819-29.

NIE, N. H., C. H. HULL, J. G. JENKINS, K. STEINBRENNER, and D. H. BENT

1975. SPSS (Statistical Package for the Social Sciences). New York: McGraw-Hill 2nd ed.

ORR, H. D., and others

1973. Introduction to Computer Programming for Biological Scientists. Boston: Allyn and Bacan, Inc.

PIANKA, E. R.

1966. Complexity, desert lizards, and spatial heterogeneity. Ecology 47:1055-59.

ROBINSON, J. V.

1981. The effect of architectural variation in habitat on a spider community: an experimental field study. Ecology 62:73-80.

SCHMID, J. A.

1975. Urban Vegetation: A Review and Chicago Case Study. Univ. Chicago, Geography Department, Research Paper 161.

SOUTHWOOD, T. R. E.

1978. Ecological Methods with Particular Reference to the Study of Insect Populations. New York: Halsted Press. p. 524.

SPECHT, H. G., and C. D. DONDALE

1960. Spider populations in New Jersey apple orchards. J. Econ. Entomol. 53:810-14.

TURNBULL, A. L.

1960. The spider population of a stand of oak (Quercus robur L.) in Wytham Wood, Berks, England. Canadian Entomol. 92:110-24.

1966. A population of spiders and their potential prey in an overgrazed pasture in eastern Ontario. Can. J. Zool. 44:557-83.

UETZ, G. W., and J. D. UNZICKER

1976. Pitfall trapping in ecological studies of wandering spiders. J. Arach. 3:101-11.

VINCENT, L. S., and G. W. FRANKIE

1985. Arthropod fauna of live oak in urban and natural stands in Texas. IV. The spider fauna (Araneae). J. Kansas Entomol. Soc. 58:378-85.

WHITCOMB, W. H., H. EXLINE, and R. C. HUNTER

1963. Spiders of the Arkansas cotton field. Ann. Entomol. Soc. Amer. 56:653-60.. 
Continued from inside front cover.

more humid. The aerial and ground-surface spider communities resembled the urban and native habitats, respectively.

Plant architecture in conjunction with local climate influenced aerial spider community composition. A greater diversity of plant species provided a heterogeneous habitat for aerial spiders at both urban and semi-native habitats. The cooler and more humid climates at these sites reduced exposure to potentially limiting factors such as desiccation. Low diversity of plant architecture and a hot and dry climate restricted aerial spider numbers and species at the native site.

Greater numbers of ground-surface spiders at the native and seminative habitats were probably due to an abundance of prey, while owner manipulation of urban gardens negatively influenced ground-surface spider numbers and species at the urban habitat.

The University of California, in compliance with the Civil Rights Act of 1964, Title IX of the Education Amendments of 1972, and the Rehabilitation Act of 1973, does not discriminate on the basis of race, creed, religion, color, national origin, sex, or mental or physical handicap in any of its programs or activities, or with respect to any of its employment policies, practices, or procedures. The University of California does not discriminate on the basis of age ancestry, sexual orientation, marital status, citizenship, medical condition (as defined in section 12926 of the California Government Code). nor because individuals are disabled or Vietnam era veterans. Inquiries regarding this policy may be directed to the Personne Studies and Affirmative Action Manager. Division of Agriculture and Natural Resources, 2120 University Avenue, University of California, Berkeley, California 94720, (415) 644-4270. 


\section{HILGARDIA Editorial Board}

Edward S. Sylvester, Chairman, Berkeley (entomology, insecticides, ecology, environmental toxicology)

Peter Berck, Associate Editor, Berkeley (economics, statistics, resource management)

Harry W. Colvin, Associate Editor, Davis (animal science, physiology, breeding, zoology, genetics)

Donald J. Durzan, Associate Editor, Davis (tree fruit and nut crops)

Walter G. Jennings, Associate Editor, Davis (food science, nutrition, and chemistry)

John Letey, Associate Editor, Riverside (soils, plant nutrition, agronomy, agricultural engineering, water)

(field and row crops)

Irwin P. Ting, Associate Editor, Riverside (botany, plant physiology, biochemistry)

Richard V. Venne, Managing Editor, Berkeley

The Journal HILGARDIA is published irregularly. Number of pages and number of issues vary per annually numbered volume. Address: Agriculture and Natural Resources Publications, University of California, Berkeley, CA 94720. 